lar automata (Stephen Wolfram's classification and modifications thereof), physics (statistical mechanics, spin glasses, hierarchical structures) and probability (different notions of mixing in ergodic theory). But rather than presenting a hodgepodge of ideas, the authors have neatly organized the discussion around a common theme: the symbolic dynamics of a one-dimensional, stationary symbol sequence. They argue that many interesting problems fall into this framework, and use it as a test case to illustrate the various complexity measures.

Theapproach throughout is no-nonsense. You won't find any bedtime reading about consciousness or economics here. There is no mention of more ambitious but speculative views of complexity, such as Per Bak's self-organized criticality or Stuart Kauffman's evolution on rugged fitness landscapes. But for a mathematically mature reader determined to ponder what complexity might mean, this book will provide some rewarding exercise.

Steven H. Strogatz is in the Department of Theoretical and Applied Mechanics and the Center for Applied Mathematics, Cornell University, Ithaca, New York 14853, USA.

\section{Truth buried in}

\section{history}

\section{This is Biology: The Science of the Living World}

by Ernst Mayr

Harvard University Press: 1997. Pp. 327.

$\$ 29.95$, £19.95.

\section{David Baltimore}

In this wide-ranging book, Ernst Mayr, one of the doyens of evolutionary biology, raises many important questions about the nature of biological research. He examines them in a scholarly yet approachable way. It is not an easy book to read, but it is rewarding.

A key question for Mayr is why physics is so different from biology. He emphasizes the purely historical aspect of biology absent in physics: physical events follow from a few laws and facts whereas biological systems are the product of natural selection that has chance as its substrate. To explain why any particular biological system exists at any one time requires constructing a 'historical narrative' that cannot be proved to be true because its truth is buried in history.

This argument, while basically sound, leaves out an important aspect of biology: even though any particular bit ofbiology is the product of evolution, it is alsolawful. After all, one can do experiments and get reproducible results. Although Mayr does distinguish between these two aspects of biology - he recognizes that biological systems must obey the laws of physics and chemistry - this law- ful component is to him less interesting than the evolutionary component. As a molecular biologist, I am tempted to say that he has missed the point of the past 50 years in biology. I am persuaded, however, that this is not the case. Rather, he is more comfortable fighting the battles of evolutionarybiology in their pure state.

Mayr takes the philosophers of science to task for forming their analyses of science from examples in physics and then generalizing to all of science. He argues that the historical side of biologyrequires it to have a different philosophy. Having grown up reading the logical positivists and wondering why they made no sense, I too have a sympathy for this view. Mayr puts Thomas Kuhn in the camp of the physically oriented philosophers. Although Kuhn does focus on physics, he was to me the first philosopher of science who made sense. Kuhn's notion of paradigm shifts particularly bothers Mayr. But, having lived through some authentic paradigm shifts in biology (maybe even helping to create one), I believe that here Mayr becomes myopic in concentrating only on the evolutionary side of biology and ignoring the lawful side of molecular biology where paradigms regularly rise and fall.

Mayr often emphasizes 'genetic programs' as the basis of the functioning of biological systems but he never carries his treatment of them very far. I think he is right that a major contribution of modern biology to evolutionary thinking is to see the changes over evolutionary time more as changes in programs of genetic expression than as changes in structural genes. It would be interesting to know from Mayr how this changed perspective influences evolutionary theory.

There is much more in the book, so much that at timesit losesfocusand becomes astream of discussion. Not a gently flowing stream either: it plunges into many arguments in evolutionary biology, outlining the development of concepts and Mayr's present views - but with few examples from the natural world.

Mayr comes across as a man of fine, liberal sentiments who has lived though the wars of modern evolutionary theory and now enjoys reflecting on them. He ends with a chapter called "Can evolution account for ethics?" in which he comes down on the side of "evolutionary humanism", saying that every person "shares a responsibility for the future of our species" which is "as much a part of cultural ethics as concern for the individual". This is Mayr's shot at the ethics of the selfish gene because he believes that arguments for altruism based on shared genes are insufficient to generate ethical norms in an interdependent society. He never deals with the nasty arguments against group selection which have always left me frustrated because my instinct agrees with him - there must be group selection, but I have not yet seen the way around selectivist arguments in favour of the gene as the unit of selection.
This is a book designed to make one think. Difficult to penetrate in places, and sometimes fairly technical, its scope encompasses deep issues. Particularly enjoyable is the chapteron human evolution, which seems to me (a rank amateur in this part ofbiology) thoughtful and illuminating. Mayr raises the fascinating question of how we humans have been able to change our society so remarkably in the past thousands of years - occupying many niches of climate and geography without much change in our gene pool. It is just one of many unanswered questions that course through his fertile brain and have found an outlet in this volume.

David Baltimore is at the Massachusetts Institute of Technology, Cambridge, Massachusetts 02139-4307, USA.

\section{Corrections}

- In his review of Who Gave Pinta to the Santa Maria? Tropical Diseases in a Temperate Climate by Robert S. Desowitz (Nature 387, 36; 1997), Len Goodwin says that the book has no index. This is true only of the advance proof copy he was sent for review, not the finished version of the book.

- In Jeremy Hyams's review of Life Itself (Nature $386,778 ; 1997)$, the book's author, Boyce Rens berger, is incorrectly described as having attended the physiology course at Woods Hole Oceanographic Institute in Massachusetts, rather than the Marine Biological Laboratory. The laboratory has held a physiology summer course in Woods Hole for over a hundred years, and has been operating a science-writing fellowship programme since 1986, of which Rensberger now serves as co-director.

\section{Rhône-Poulenc Science Book Prize}

The winner of this year's £10,000 Rhône-Poulenc Science Book Prize will be announced at the Science Museum in London this week. On the shortlist are: Climbing Mount Improbable by Richard Dawkins (Penguin, £7.99; pbk). Vigorous popularization of the power and scope of natural selection. Reviewed in Nature 382, 309 (1996).

Fire in the Mind: Science, Faith and the Search for Order by George Johnson (Penguin, £8.99; pbk). Complexity, Santa Fe-style.

\section{IntheBlood:God,Genes andDestiny by Steve}

Jones (Flamingo, £12.99; pbk). Panoramic view of genetics and human history. Reviewed in Nature 382, 413(1996).

The Origins of Virtue by Matt Ridley (Viking, $£ 20$; hbk). Evolution of altruism and cooperation. Reviewed in Nature 383, 785 (1996).

Longitude by Dava Sobel (Fourth Estate, $£ 12$; hbk). How an eighteenth-century clockmaker invented a way of working out location at sea. Reviewed in Nature 385, 309 (1996).

The Wisdom of the Bones: In Search of Human Origins by Alan Walker and Pat Shipman (Phoenix, $£ 7.99 ;$ pbk). Husband-and-wife team recount Walker's 1984 discovery of a 1.5-million-year-old Homo erectus skeleton dubbed Nariokotome boy. 


\section{Travels with diseases}

\section{Who gave Pinta to the Santa Maria? Tropical Diseases in a Temperate Climate \\ by Robert S. Desowitz \\ Norton: 1997. Pp. 228. \$25 \\ Len Goodwin}

Bob Desowitz has spent many years in tropical countries as a researcher and teacher of parasitology. He is now a bearded patriarch with an emeritus chair in Honolulu, and from time to time he sets down his view of the past, present and future of some aspect of the science.

The parasites of animals developed and varied along with their hosts and, when the continents separated, those in the New World took different lines from those in the Old. So it is not surprising that the exchange of people and parasites that occurred during the age of discovery led to epidemics of disease that changed the course of history, the maps of the world and the fate of nations. Desowitz outlines some of the most exciting.

European sailors took home spirochaetes from America and started an epidemic of syphilis. The pinta of the book's title is a skin infection. Missionaries carried measles, smallpox and benign tertiary malaria to the New World, and the slaves from Africa added malignant malaria. The epidemics of unknown diseases, together with terror and despair, killed off most of the Amerindians.

Yellow fever had a profound effect. Desowitz describes the epidemics that enabled the United States to buy vast areas of land that the European powers could no longer support. He describes the work of Wal-

\section{New in paperback}

\section{Why Things Bite Back: Predicting the Problems of Progress \\ by Edward Tenner \\ Fourth Estate, $£ 7.99$ \\ A look at the paradoxes and unintended consequences of technology. It "offers a much- needed healthy balance between contemporary technological utopian fantasies and neo-Luddite despair. This superb guide to our high-tech world deserves a wide readership", wrote Howard P. Segal in Nature 382, 504 (1996).}

\section{The Same and Not the Same}

by Roald Hoffmann

Columbia University Press, $\$ 22.50$

A guide for the general reader to the art and science of chemistry. "Roald Hoffmann wants to tell readers not why chemistry is important but why he loves it", wrote Philip Ball in Nature 380, 34 (1996). ter Reed's team that elucidated the transmission of the virus by mosquitoes. By targeting the species of mosquitoes that carry yellow fever and malaria, William Crawford Gorgas was able to complete the construction of the Panama Canal, which had been abandoned by the French.

There is an interesting description of the influence of the millionaire philanthropist John D. Rockefeller and the foundation he financed in clearing hookworm from the southern United States, helping to control malaria and dealing a final blow to yellow fever by the development of a safe vaccine.

Exotic disease is at present under control in temperate countries but new introductions are a constant danger, as shown by unexpected outbreaks, usually traceable to immigrants from endemic areas. Temperate climates can support the vectors of many tropical infections and, with global warming, are likely to become even more favourable. South American trypanosomiasis or Chagas' disease is carried by a bug; suitable species, together with reservoir hosts - ground squirrels and dogs - are widely distributed in the United States. It would not be too difficult for an epidemic to occur and there is no really effective treatment. Also, as the remaining tracts of wilderness are invaded, new infections such as Kyanasur Forest and Ebola viruses may be transmitted from animals to humans.

New drugs for exotic diseases are not a priority for the pharmaceutical industry, although the old cures are becoming less effective. A serious situation could develop before long. Desowitz makes the point that fundamental discoveries that have changed the face of medicine have often come from completely unrelated fields of science and he appeals for more support to be given to basic research with no immediate short-term targets.

The style is chatty, wry and racy - the book was probably derived from popular lectures or student seminars - and the narrative is broken by frequent philosophical digressions, personal recollections and anecdotes. There are a few terrible illustrations but a dearth of references and no index. It would make ideal, informative reading for a fairly long flight to a tropical country.

Len Goodwin is at Shepperlands Farm,

Park Lane, Finchampstead,

Berkshire RG40 4QF, UK.

\section{New journals}

This year, Nature's annual new journals review supplement will appear in the issue of 11 September. Publishers and learned societies are invited to submit journals for review, as well as details of any eligible electronic journals, taking note of the

following criteria:

- Journals that first appeared during or after June 1995 and issued at least four separate numbers by the end of May 1997 will be considered.

- Journals covering any aspect of science are eligible, although those dealing with clinical medicine and pure mathematics are excluded, as are publications of abstracts.

- Frequency of publication must be at least three times a year. The main language used must be English. Translation journals in English are, of course, eligible.

- Deadline for submission is 6 June. When submitting journals for review, please send at least four different issues (the first, the most recent and any two others) of each title, together with full details of subscription rates. For further information please contact Peter Tallack, Nature, Macmillan Magazines, Porters South, Crinan Street, London N1 9XW, UK. Tel: +44 (0)171 8434567.

e-mail: p.tallack@nature.com.

\section{The Song of the Dodo: Island Biogeography in an Age of Extinction}

by David Quammen

Simon \& Schuster, \$17

David Quammen "summarizes in exciting, earthy prose what he learned about island biology and species extinction during eight years of adventurous travel, reading and conversation. Descriptions of places alternate with chapters on the history of ideas and accounts of conversations with biologists", wrote Lawrence B. Slobodkin in Nature 381, 205 (1996).

Altered States: Gene Therapy and
the Retooling of Human Life
by Jeff Lyon and Peter Gorner
Norton, $\$ 15.95, £ 11.95$
Reviewed by David Weatherall in Nature 375 ,
545 (1995).

Grooming, Gossip and the Evolution of Human Language

by Robin Dunbar

Faber, $£ 7.99$

Reviewed by Derek Bickerton in Nature 380, 303 (1996).

The Artful Universe: The Cosmic Source of Human Creativity

by John D. Barrow

Penguin, £12.50; Little Brown \$17.95

Reviewed by Christopher Longuet-Higgins in Nature 379, 216 (1996).

The Neanderthal Enigma: Solving the Mystery of Modern Human Origins

by James Shreeve

Penguin, £8.99; Avon Books \$14

Reviewed by Jean-Jacques Hublin in

Nature 381, 658 (1996). 


\section{Soft cell}

\section{Life Itself}

by Boyce Rensberger

Oxford University Press: 1997. Pp. 290. \$30,

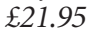

\section{Jeremy Hyams}

The list of past students of the physiology course at Woods Hole Oceanographic Institution in Massachusetts reads like a who's who of cell biology. In the summer of 1987, the student body included the Washington Post science writer, Boyce Rensberger. The four weeks he spent in the beautiful surroundings of the Marine Biology Laboratory were to prove the start of two love affairs - one with a fellow student whom he subsequently married, the other with the living cell. Life Itselfis the product of the second infatuation.

Cell biology is a field unusually rich in excellent textbooks. Most are written by cell biologists for cell biologists. They are mostly lavishly illustrated and written with a measured authority befitting the status of their often highly distinguished authors. Life Itself

is like none of these. Although its structure is fairly classical, with chapters on membranes, organelles, DNA structure, protein synthesis, mitosis and so on, the style certainly is not.

For Rensberger, a macrophage is a "great hulking predator brooding silently in the dim light waiting for some signal that prey had blundered into its vicinity". Platelets are the body's "911 Rescue Squad, a SWAT team, a Rapid Deployment Force, a Red Cross, and a few other emergency response mechanisms". The nucleus is a "giant brooding dome off to one side of the cell" (later it's a Volkswagen Beetle or the yolk in a fried egg). Chaperones work "like a sculptor modifying an unsatisfactory clay figure... massaging the amino acid chain, nudging a helix sideways, or shifting a loop from this side to that". The endoplasmic reticulum is a "hot air balloon". Microtubules grow out from centrioles, "making them look like two dandelions gone to seed".

The recurring theme is the cell as a living room, with the nucleus like the Beetle parked to one side (presumably there is an integral garage - or perhaps I am starting to take all this a bit too seriously). Membranes are the walls, and the organelles are sausages, grape-

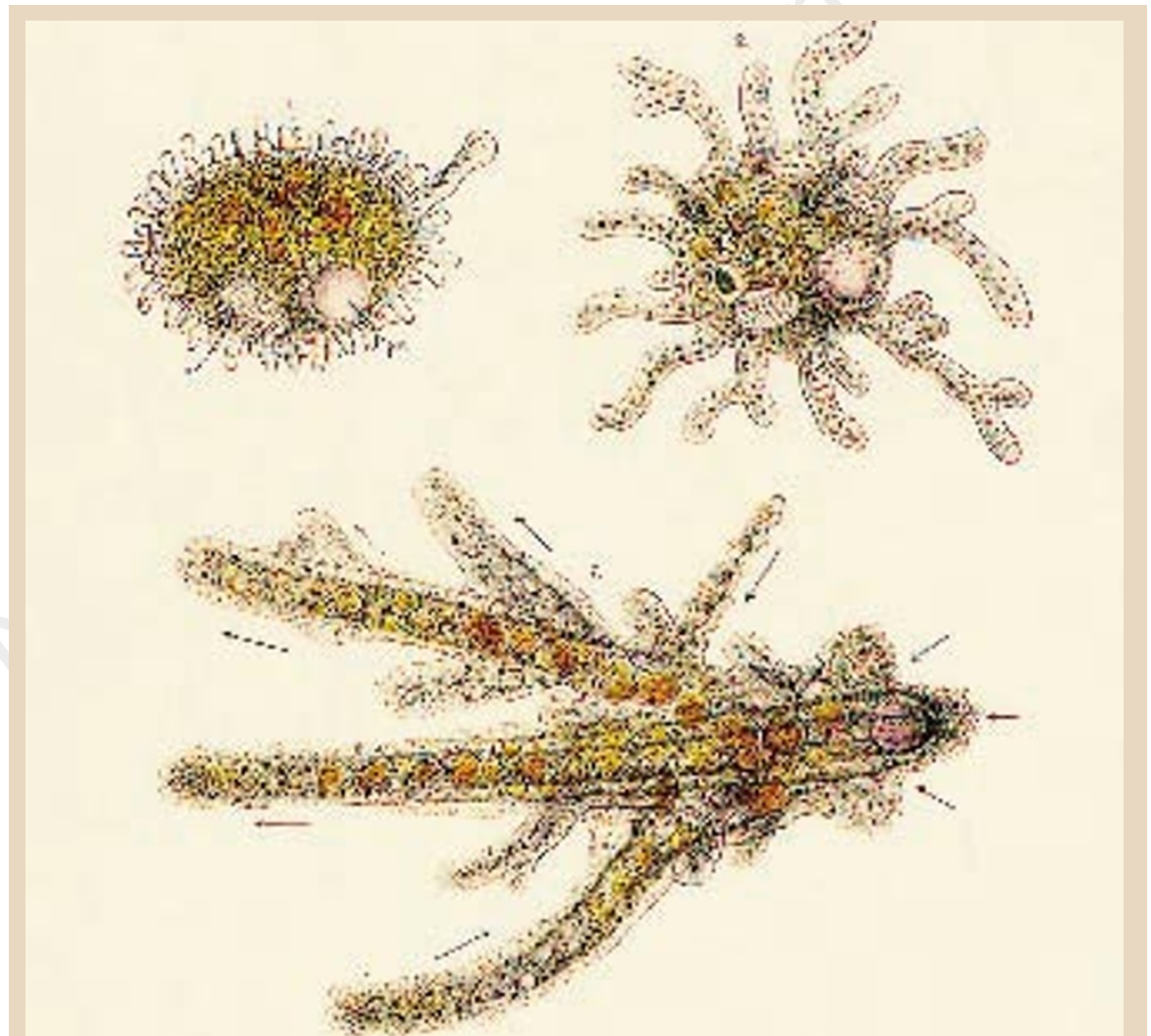

\section{The little changeling}

The common freshwater amoeba was first described in 1755 by the German naturalist and miniature painter Roesel von Rosenhof who called it "der kleine Proteus" after the Greek sea god who could change his shape at will. It was given its official name Amoeba proteus by the American Joseph Leidy, whose beautifully illustrated Fresh-water Rhizopods of North
America, a plate of which is reproduced here, was published in 1879. The picture is one of 60 drawings and photographs chosen by Joseph $\mathrm{G}$. Gall in Views of the Cell: A Pictorial History (American Society for Cell Biology, \$29). With the author's accompanying descriptions and historical analysis, the images pay homage to the pioneers of microscopy and cell biology. fruit and basketballs. The sperm head is the size of an overstuffed chair and the sperm must swim nearly 2,000 miles, "drawn by the egg's perfume!". Perhaps the style owes more to Alice in Wonderland than it does to Molecular Biology of the Cell but, once one has convinced oneself that it is not some elaborate joke, it becomes quite compelling.

Rensberger's fascination with cells clearly also applies to the people who study them. He frequently resorts to the journalist's stock in trade, the snappy quotation. Many famous cell biologists make cameo appearances to offer personal comments on their particular specialities. Although some of the descriptions are rather lurid, what cannot be disputed is Rensberger's wonderment and enthusiasm because it literally leaps off the page. Here is the little boy who has been locked in the chocolate factory overnight, determined to gobble up as much as possible before the morning shift arrives and sends him home to his mum. It is all good, clean fun and, in truth, a rather remarkable achievement for a nonprofessional. (I hesitate to call someone who has managed to publish a picture of a cytoskeleton on the front page of a serious national newspaper an amateur.)

I am not entirely sure who Life Itself is aimed at. Presumably it is not intended to go up against the established cell biology tomes but it is hard to imagine a better way to convey to students the thrill of looking down a microscope at a living cell - and they get a pretty respectable introduction to cell structure and function thrown in for good measure. If Rensberger's other love affair is as successful as this one, he is a lucky chap. Jeremy Hyams is in the Department of Biology, University College London, Gower Street, London WCIE 6BT, UK.

\section{New journals}

This year, Nature's annual new journals review supplement will appear in the issue of 11 September. Publishers and learned societies are invited to submit journals for review, as well as details of any eligible electronic journals, taking note of the following criteria:

- Journals must have first appeared during or after June 1995 and issued at least four separate numbers by the end of May 1997. - Journals covering any aspect of science are eligible, although those dealing with clinical medicine and pure mathematics are excluded, as are publications of abstracts.

- Frequency of publication must be at least three times a year.

- Deadline for submission is 6 June.

When submitting journals for review, please send at least four different issues (the first, the most recent and any two others) of each title, together with full details of subscription rates. For further information contact Peter Tallack, Nature, Macmillan Magazines, Porters South, Crinan Street, London N1 9XW, UK. Tel: +44 (0)171 843 4567. e-mail: p.tallack@nature.com. 